研究

\title{
ステンレス鋼粉の焼結促進に対するフラックス添加の効果
}

\author{
韓剛杄，多田 充伸幻，黒木 英憲汭，篠崎 賢二幼

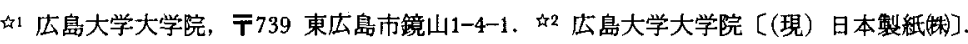 \\ 出 3 広島大学工学部第一類, $\mathbf{T} 739$ 東広島市鏡山1-4-1.
}

\section{Effect of Flux Addition on Enhancement of Sintering in Stainless Steel Powder Compacts}

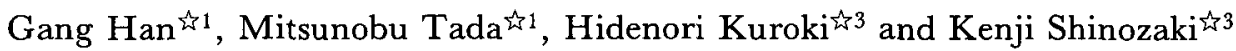

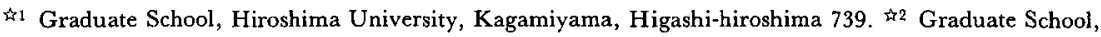 \\ Hiroshima Univ., [Present Address: Nippon Paper Industries Co.]. क्म3 Dept. Mechanical Engineering, \\ Hiroshima Univ., Kagamiyama, Higashi-hiroshima 739.
}

Received February 6, 1995

\section{SYNOPSIS}

The sintering of stainless steel powder ( -100 mesh water-atomized SUS316L powder) compacts by use of fluxing has been tried. As a result, it was found that the sintering was activated noticeably by the addition of a small amount of flux. A sintered density of $94.5 \%$ was achieved with a 2 mass $\%$ of $\mathrm{Na}_{2} \mathrm{~B} 4 \mathrm{O} 7$ as the flux for a compact having a green density of $77.2 \%$ by sintering it at $1620 \mathrm{~K}$ for $60 \mathrm{~min}$ in vacuum. Without the flux, a compact sintered in the same conditions had a density of $85.4 \%$. We think the enhancement of the sintering is associated with the removal of oxide from the surface of the steel particle and the liquid phase sintering following the formation of a $\mathrm{Fe}-\mathrm{Cr}-\mathrm{B}$ eutectic liquid. The flux became a slag including $\mathrm{SiO} 2, \mathrm{MnO}$ and $\mathrm{Na} 2 \mathrm{O}$ in the spherical pores during sintering.

\section{KEY WORDS}

stainless steel powder, surface oxide, flux, activated sintering, liquid phase sintering.

\section{1 緒 言}

ステンレス鋼は高濃度のクロムの外，脱酸材とし てシリコンとマンガンもある程度含有している。 そ のため, Ferriss"の表面分析結果によれば, 316L ステンレス鋼アトマイズ粉末の表面には, $\mathrm{SiO}_{2}$, $\mathrm{Cr}_{2} \mathrm{O}_{3}, \mathrm{Fe}_{2} \mathrm{O}_{3}$ の酸化膜がある. また, 0lef jordら ${ }^{2)}$ によるフェライト系ステンレス鋼アトマイズ粉末の 表面分析でも， $\mathrm{SiO}_{2} ， \mathrm{HnO}, \mathrm{Cr}_{2} \mathrm{O}_{3}, \mathrm{Fe}_{2} \mathrm{O}_{3}$ からなる 酸化膜層が平均 $15 \mathrm{~nm}$ 程度確認されている。これらの 原料粉を用いる粉末治金部品を工業的に焼結する際， 真空中または還元雾囲気中では, $\mathrm{Cr}_{2} \mathrm{O}_{3}$ 及び $\mathrm{Fe}_{2} \mathrm{O}_{3}$ は
蒸発或いは還元による除去が容易である，しかし， $\mathrm{SiO}_{2}$ やnn0のような酸化膜の除去は困難と言われて いる3.4)。このような酸化膜の存在は，粒子間の接 点領域に金属ネックを成長させる上で障害になる。 しかむ，オーステナイト系ステンレス鎆粉単独の圧 粉体は，一般的な鉄系機械部品に用いられる1400K 付近の焼結温度では $\gamma$ 単相であるため，元素の搪散 が遅く，その点からも高密度の焼結体を得ることが 難しい。

オーステナイト系ステンレス鋼㸮の焼結促進方法 として，焼結温度と合金成分の調整による $(\gamma / \delta)$ 
Table 1. Composition and size distribution of water-atomized SUS316L powder.

\begin{tabular}{c|c|c|c|c|c|c|c|c}
\hline element & $\mathrm{C}$ & $\mathrm{Si}$ & $\mathrm{Hn}_{\mathrm{n}}$ & $\mathrm{P}$ & $\mathrm{S}$ & $\mathrm{Ni}$ & $\mathrm{Cr}$ & Ho \\
\hline mass\% & 0.015 & 0.81 & 0.20 & 0.020 & 0.008 & 12.87 & 16.92 & 2.04 \\
\hline mesh & +100 & $-100+145$ & $-145+200$ & $-200+250$ & $-250+350$ & -350 \\
\hline mass\% & 0.1 & 10.0 & 19.7 & 10.4 & 22.5 & 37.3 \\
\hline
\end{tabular}

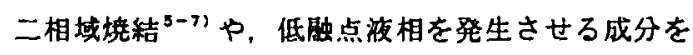
添加する液相焼結 ${ }^{8-10)}$ がよく知られている. しか

し、化膜の障害作用を低隇，消隇させる力向の研 器例は，黒路を加えて酸素をCOガスとして除去する もの”以外，绐ど見当たらない，岸利用は，才

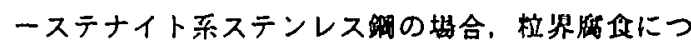
なが恐れがあり，好ましくない。

他方，ろう付では，母材とろう材とのぬれ性を向 上させるため，酸化物に对して高い反応性を持つつ ラックスを使い，母材表面の酸化物を溶解して接合 を実現している゙'”。この方法を利用すれば，金属 物末でもフラックスの添加によって表面酸化膜を取 り除き，清浄な粉末柆子同士の焟結が可能亡思われ ろ.しかも，物末治金部品はもともと多孔質であり， 気孔に残るスラグが化学的に安定であれば材料特性 には必ずしも悪影湆を生じないであろう，既にLund らは，炭酸塩フラックスを添加した場合に，鉄一黒 鈶系材料の浸炭を促進する勃果 '2)を報告している。 また，Fe-Si系材料の焼結時に，シリコン粒子表面 の酸化膜の除去とシリコンの挂散合金化を促進する

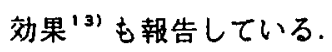

そこで，オーステナイト系ステンレス鎆粉に，乃 う付用フラックスとして一般的なホウ酸ナトリウム を添加して効果を調へたところ，焼結緻密化を大幅 に促進できることが分かった：この結果を受け，本 研究では，焼結密度に及ぼすフラックス添加量と焼 結条件の影製を調へてている.

\section{2 実検方法}

原料粉末として，-100meshのSUS316L粉末（大同 特殊銅(株)製) を用いた，同社による成分と粒度分 布の測定值をTable 1に示す.フラックスは市販の 試薬 $\mathrm{Na}_{2} \mathrm{~B}_{4} \mathrm{O}_{7} \cdot 10 \mathrm{H}_{2} \mathrm{O}$ (片山化学工業(株)㱔)である. これを、結晶水を含まない $\mathrm{Na}_{2} \mathrm{~B}_{4} \mathrm{O}_{2}$ として所定量に

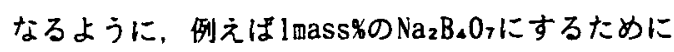
は1.89年ass\%の $\mathrm{Na}_{2} \mathrm{~B}_{4} \mathrm{O}_{7} \cdot 10 \mathrm{H}_{2} \mathrm{O}$ を科量し，蒸留水に溶
解して鋮粉に加えた。をして摫挷しながら470Kに加 熟し，加えた水と結晶水の一部を蒸発させた。 残留 水分はホウ酸ナトリウム添加量に対して45mass\%で あり、全部が結晶水として存在しているとすれば， $\mathrm{Na}_{2} \mathrm{~B}_{4} \mathrm{O}$ 衤に対してほほ5 量测定によれば、この残留水分は成形後の脱ろう中 に70\%が筣発し、さらに䒨結時の1014Kまでの加熟で 残りも筧発する。

これらの混合粉末を、ステアリン酸で型壁潤滑し た金型て600MPaて压縮し，5mm立方の圧物体を作製 した。 その後，770Kに保持した分解アンモニア第囲 気炉で30min脱ろうし，アルコン雾囲気または真空 中 $\left(5 \times 10^{-3} \mathrm{~Pa}\right)$ で焼結温度や焼結時間を変えて㛭 結を行った。熎結中の加熟と椧却速度は10K/minを 基本としたか，一部には特に記しているように水冷 したものもある.

以上の手順で得られた焼結体の密度をアルキメテ ス法で測定し，さらにその焼結体の中央部を切断し て研磨後，組織を観察した。この際，組織の定量的 評価には画像解析装置（ピアス(株)製，LA-500型） を用いた。なお，焼結密度はSUS316L鋼の理論密度 の8. $06 \mathrm{Hg} / \mathrm{m}^{3}$ に対する相対密度として表示した。

\section{3 実䖽結果}

3.1 フラックス添加による物末の圧縮性の変化

王物密度とフラックス添加量の関係をFig.1に実 線で示す.これによると，压粉密度はフラックス量 1mass\%付近までほほ一定しているが，それ以上添加 すると隇少する。なお，ステンレス鎆とホウ酸ナト リウムの混合粉について， $\mathrm{Na}_{2} \mathrm{~B}_{4} \mathrm{O}_{7} \cdot 5 \mathrm{H}_{2} \mathrm{O}$ の密度を $1.81 \mathrm{Mg} / \mathrm{m}^{3}$ として ${ }^{(4)}$ ，後述の混合則で期待される圧 㸮密度を計算し，結果を破線で併示している。

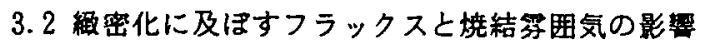

Fig. 2に示すのは，㜔結密度に及ぼすフラックス 添加量亡焼結第囲気の影整である．同図によると， 密度はフラックス無添加より增加する傾向になって 


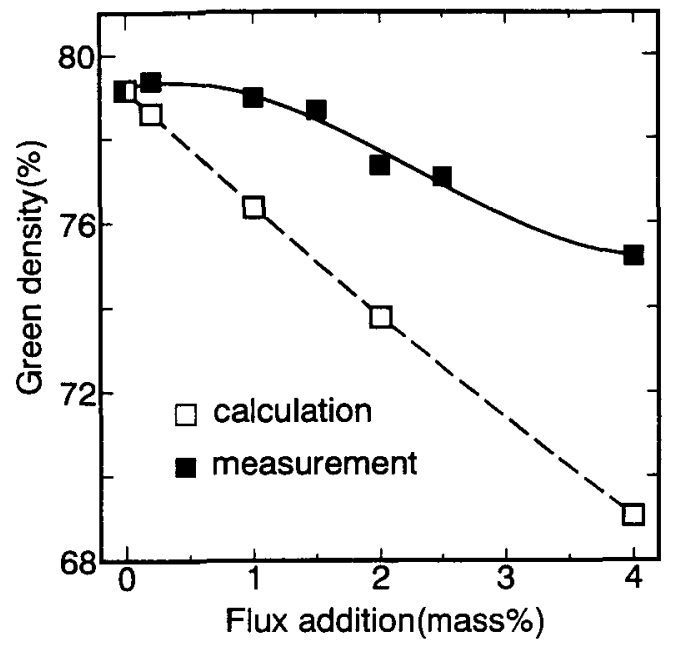

Fig.1 Effect of flux addition on green density.

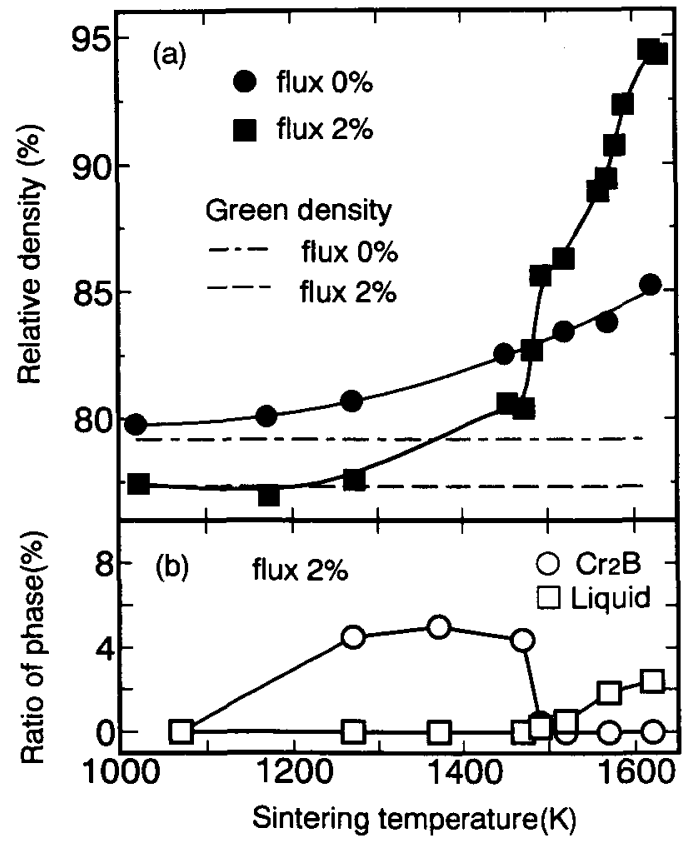

Fig.3 Effect of sintering temperature on density and phase ratios of compacts sintered for $60 \mathrm{~min}$ in vacuum, and cooled slowly(a) or quenched in water(b).

いろ. まず1520Kでは，真空とアルゴンガス票囲気 の両方ともほ同し挙動をする，焼結密度は1〜 2ஐass\%フラックス添加によって增加するが, 2mass\% と4mass\%の添加では殆ど変わらない，次に1620Kて は，真空中でフラックス添加量2mass\%ぐらいの場合

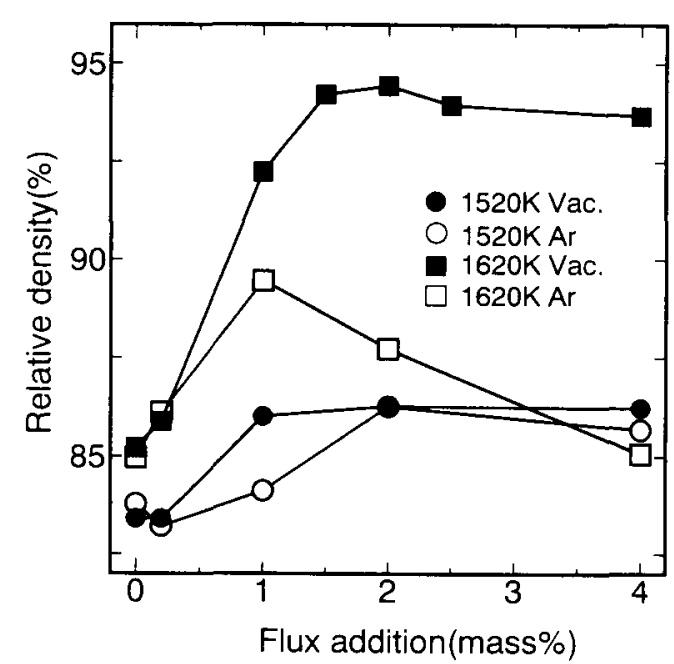

Fig.2 Effect of flux addition and atmosphere on density of compacts sintered for $60 \mathrm{~min}$ and cooled slowly.

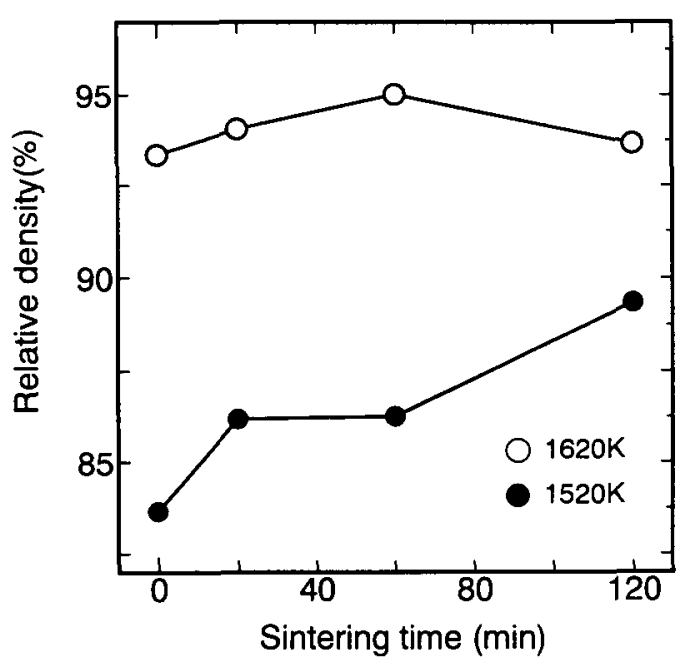

Fig.4 Effect of sintering time on density of compacts pressed with 2 mass $\%$ of flux, sintered in vacuum and cooled slowly.

に焼結密度が最大になり，2mass\%を越えると小さな 密度隇少になる。をれに対しアルゴンガス雾囲気で は，密度がフラックス添加量1mass\%で最大になり， 1西ass\%を越えると大幅に隇少する，しかむ，真空で は94.5\%の最高密度を得ているか，アルコンでは90\% を越えない，雾囲気の影製を比へろと、アルコンガ ス丞囲気の焼結密度の最大值は真空のそれより小さい． 従って，以後の燎結はすへて真空中で行っている. 

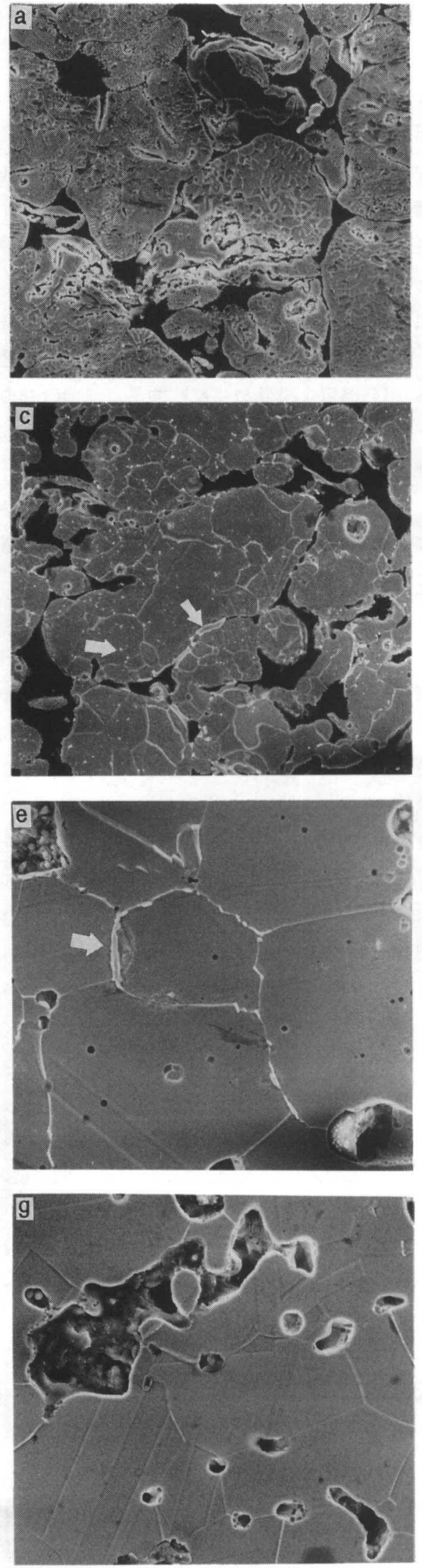

1995年 8 月
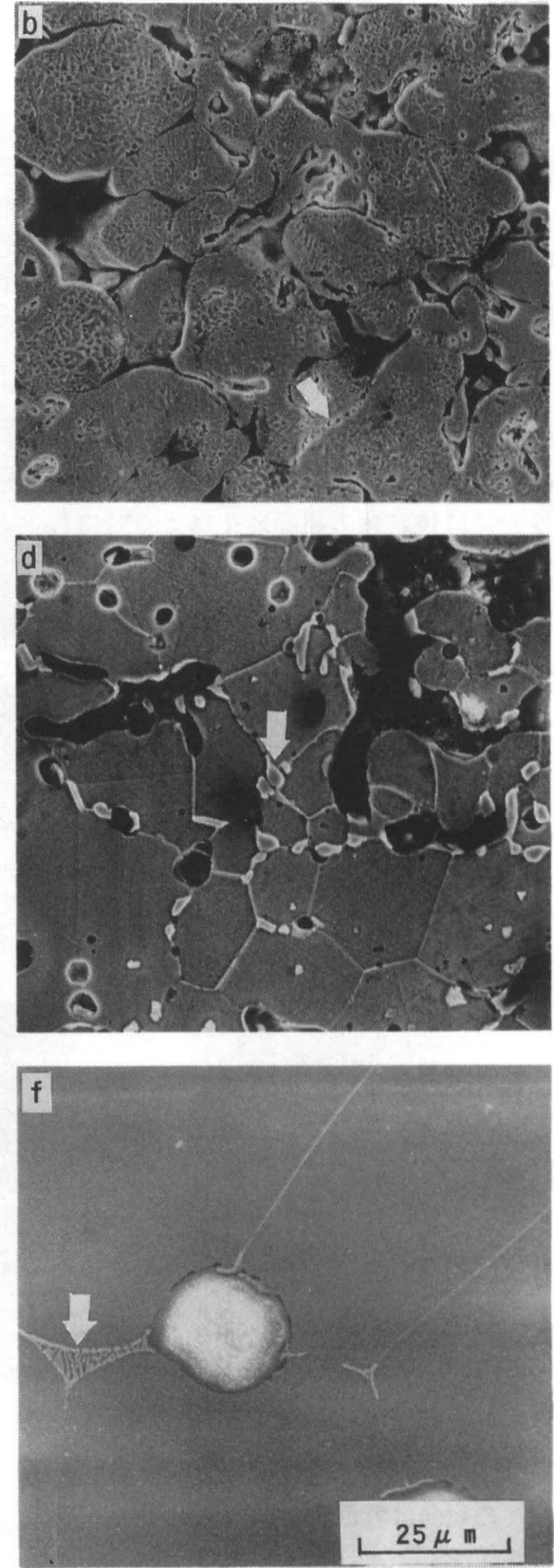

Photo.1 SEM micrographs on sections of compacts sintered at different temperatures for $60 \mathrm{~min}$ in vacuum, cooled slowly and etched in Marble's Reagent. a:1030K b:1070K c:1270K d:1470K e:1490K f:1620K g:1620K

a e:with 2mass\% $\mathrm{Na}_{2} \mathrm{~B}_{4} \mathrm{O} 7$ g:without flux 


\section{3 緻密化に及ぼす焼結温度の影繁}

焼結密度に及ほす焼結温度の影響をFig. 3(a)に示 す. 同図のフラックス無添加の場合、焼結温度の上 昇に連れて真空中60min焼結の密度は少しずつ增加 するが，実験した最高温度1640Kで86\%程度である。 それに対し，2唯添添加した場合の密度は1270K以 下ては殆ど增加しないが，1270Kを越えると勾配が 大きくなる．特に1470Kを越えると密度が著しく增 加し， $1620 \mathrm{~K}$ 付近で94.5\%の最大値を得ている.

\section{4 組織に及ほす焼結温度の影慗}

以上の密度変化は㛘結体の組織変化によく对応し ている.フラックスを2些的加え，真空中で焼結温 度を贸えて60min焼結した場合の組穖をPhoto. 1に示 す. $\mathrm{Na}_{2} \mathrm{~B}_{4} \mathrm{O}_{7}$ の虽点は $1014 \mathrm{~K}^{15)}$ であり、1014K以上で フラックスは液相になり，ステンレス鋼㸮粒子の表 面を临うはずであるが，Photo.1(a)に見るように， 1030Kで鋼粉柆子の表面に特別の相は認められない. しかし，(b)の1070Kで，銅粉粒子表面にわすが粒 状物（矢印で示す）か観察され，その粒状物が焼結 温度の上昇に連れて增加する．しかも（c）のよう に鋮粉柆内で $0.2 \mu$ 品下の緗かい分散粒子になって いるものと，粒界で数 $\mu$ mの大きさになっているも のが見える。

1470Kまで昇温すると(d)のように柆内の細かい柆 子が消え，杧哭の大きい粒状物が壬くなる。:この段

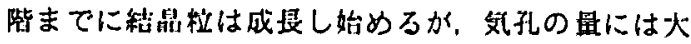

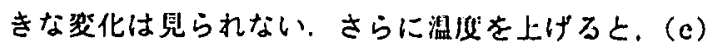
の1490Kのように柆状物と気孔が急激に就少し，ま た気孔の球状化と気孔及び結昆柆の租大化が非み， 矢印で示すように結昆粒子間に膜状の新たな相が出 現し始める．この傾向は帠温と共に一層強まり， 1620Kの(f)のように，くさび型に結晶柆子間に食い 込む共晶状組織の出現及び粒状物と気孔の減少，結 晶の著しい粗大化が進む（f）の組織は，ステンレ ス鎙のマトリックスと共晶状部分の外は，フラック スだけが残って気孔は消隇しており，最高密度到逢 に対応している.

次報で述へろか，EPMA観察などによれば，白 い粒状生成物は $\mathrm{Cr}_{2} \mathrm{~B}$ であり，膜状相及び共晶状部分 はCr-Fe-Bを主としてHo, Ni 吉含む多元系液相である. マトリックスの変化と同時に，添加したフラックス がシリコン、マ、ンガンナトリウムの䙓合酸化物か
らなるスラグに変わることも確認している。一方。 フラックス無添加の方は，同じ1620K-60minでも(g) のように緻密化が進んでいない，

組織变化は，画像解析によって定量化すれば，密 度変化との対応が一層よく分かる.Fig.3(b)は，各 温度で60minの焼結後に水冷した試料について，圶 腺を除いたステンレス銅部分全体の中で， $\mathrm{Cr}_{2} \mathrm{~B}$ 柆状 物と $\mathrm{Cr}-\mathrm{Fe}-\mathrm{B}$ 多元系液相の占める面積率を示す。

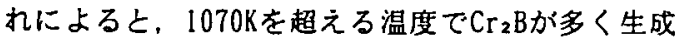
し，その量は1270K〜1470Kで4〜5\%とほほ一定檤を 保ち，1490K以上で急激に減少する。このC ${ }_{2}$ Bの城 少と入れ替りに多元系合金液相が発生し，温度の上 舁と共に3\%近くまで增加する。

\section{5 䋹密化に及ほすす暁結時間の影響}

焼結時間による密度の変化を求めてFig. 4を得た。 フラックスを2mass\%添加した場合，真空焟結による 緻密化が焼結温度までの加熱途中に著しく進んでお り，保持時間の延長は繳密化に影敕が少ない，低い 温度の1520Kでは，焼結時間が0minから120minまで 長くなれば，密度が83㔔ら89\%まで增加するが，実 はその前の1520Kまでの加熱過程だけでも，密度は 殴㸮体の77\%から83\%まで增加している．また，1620K で境結する場合は，加第過程だけで密度が93\%を越

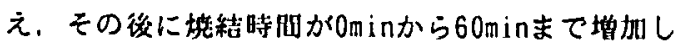
ても，密度の增加は檽く保かである，後者では時間 が120minまで延びれば，密经はかえってゃや被少す る倾问にある。

\section{4 考}

4.1 1 フラックス添扣と物末束の压縮性

Fig.1に示すように、フラックスの添加によって 王粉密度が減少する。この密度诚少は，低密度のフ ラックスがある体積を占めることの効果を含んてい るはずである．フラックスを含む冉㸮体の密度は， 無添加圧粉体の密度とフラックスの密度から湿合則 で与えられるとすれば，次のようになる。

$$
\rho=\frac{\rho_{D} \rho_{1}}{\rho_{1}+\left(\rho_{D}-\rho_{P}\right) 1.45 x / 100}
$$

ここでคはNa $\mathrm{B}_{4} \mathrm{O}$ 一をXmass\%( $\mathrm{Na}_{2} \mathrm{~B}_{4} \mathrm{O}_{7} \cdot 5 \mathrm{H}_{2} \mathrm{O} 1.45 \mathrm{X}$ mass\%)添加した場合の圧汾密度。 $\rho$ ，は $\mathrm{Na}_{2} \mathrm{~B}_{4} \mathrm{O}_{7} \cdot 5 \mathrm{H}_{2} \mathrm{O}$

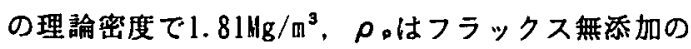



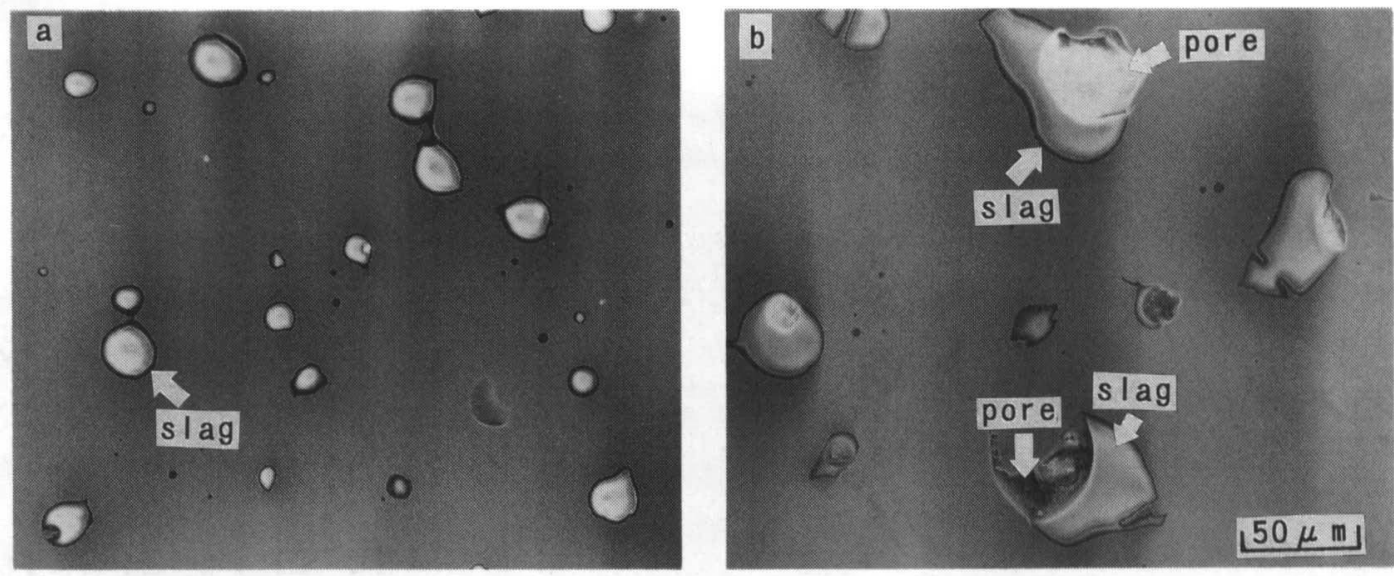

Photo.2 SEM micrographs on polished sections of compacts pressed with 2 mass $\%$ Na2 $\mathrm{B}_{4} \mathrm{O} 7$, sintered at $1620 \mathrm{~K}$ for $60 \mathrm{~min}$ in vacuum(a) and in $\operatorname{Ar}(\mathrm{b})$, and cooled slowly.

場合の同じ圧縮条件下の圧粉密度で，Fig.1による と6. $38 \mathrm{Mg} / \mathrm{m}^{3}$ である.この式の計算結果（Fig. 1 破線） に比へて，実測した圧粉密度（Fig. 1実線）の方が 高い. しかも，二つの線の差がフラックス添加量の 増加に連れて大きくなる.これは，フラックスが粉 末粒子間の摩摖を減少させ, 充填密度を上げる効果 を発揮するためと考えられる.

つまり、フラックスの添加が压粉密度に影踣する 機構はニつに分けられる。一つはフラックス自身の 密度が低いために, 混合王粉体の密度を減少させる

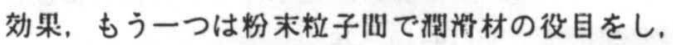
密度を上罪させる効果である.フラックス量の增加 に进れて基本的には压粉密度が減少する中で，澌湖 効果が緅やかに增大し，実測密度が咶算値から大き く䧺れるようになるのであろう.

\section{2 焼結過程に及ぼす温度の影響}

密度及び組織の変化によれば, 1030Kではフラッ クスが溶骶しても鋼粉と反応せず，1070K付近で反 応が始まって $\mathrm{Cr}_{2} \mathrm{~B}$ 粒状物が生じている，ホウ化物の 生成は表面酸化膜の除去に伴って起こると考えられ るが，広範に反応が認められるのは1270K以上であ る. 柆状物が接近した鋼粉粒子の間で生じた場合, 両方の鋼粉粒子に架橋し、一種の焼結ネックの形に なっているものが見受けられる.この粒状物が增加 する1470Kまでの範囲で，フラックス無添加材に比 へてて添加材の緻密化傾向が少し大きくなるから, 粒 状物がネックとして焼結促進効果を発揮している可 能性がある.
次報で詳しく述べかか， $\mathrm{Cr}_{2} \mathrm{~B}$ の生成とフラックス 中へのシリコンとマンガンの集中は，フラックスが 鋼粉表面の酸化膜を溶解し，さらに鋼粉本体と接触 して，次の諸反応を起こすことによると考えられる．

$$
\begin{aligned}
& \left(\mathrm{Na}_{2} \mathrm{~B}_{4} \mathrm{O}_{7}\right)=\left(\mathrm{Na}_{2} \mathrm{O}\right)+2\left(\mathrm{~B}_{2} \mathrm{O}_{3}\right) \\
& 9[\mathrm{Si}]+4 \mathrm{Cr}_{2} \mathrm{O}_{3}+2\left(\mathrm{~B}_{2} \mathrm{O}_{3}\right)=9\left(\mathrm{SiO}_{2}\right)+4 \mathrm{Cr}_{2} \mathrm{~B} \\
& 9[\mathrm{Mn}]+2 \mathrm{Cr}_{2} \mathrm{O}_{3}+\left(\mathrm{B}_{2} \mathrm{O}_{3}\right)=9(\mathrm{MnO})+2 \mathrm{Cr}_{2} \mathrm{~B} \\
& 3[\mathrm{Si}]+8[\mathrm{Cr}]+2\left(\mathrm{~B}_{2} \mathrm{O}_{3}\right)=3\left(\mathrm{SiO}_{2}\right)+4 \mathrm{Cr}_{2} \mathrm{~B} \\
& 3[\mathrm{Mn}]+4[\mathrm{Cr}]+\left(\mathrm{B}_{2} \mathrm{O}_{3}\right)=3(\mathrm{MnO})+2 \mathrm{Cr}_{2} \mathrm{~B}
\end{aligned}
$$

ここで[ ]は銅中に固溶している元甞（）はフラッ クス或いはスラグの成分を示す.

次に1470Kから1490Kへのわずか20Kの显温で，粒 状物及び気孔の減少、気孔の球状化、気孔及び結晶 柆の粗大化，そして膜状相の出現という全般的組織 変化か，急激に起こっている．1620Kで見られる共 晶状組織は，結晶粒子間にくさび型に食い込む形に なっており，焼結時に現れる液相の特徽 ${ }^{(0)}$ をよく 示しているが、この液相が既に1490Kで現れたので あろう. 液相の発生は, 初めに生じた $\mathrm{Cr}_{2} \mathrm{~B}$ がステン レス鎆マトリックスと反応し, $\mathrm{Fe}-\mathrm{Cr}$-Bを主として $\mathrm{Ni}$, Hoも含む多元系共晶液相を生成する現象と考え られる、1470Kを超える温度で、液相の增加と最も 大幅な緻密化が対応しているので，緻密化に及ぼす フラックス添加の主な効果は, 多元系液相を発生さ せ，一般的液相焼結機構を働かせたことであると思 われる、それによって粒子の再配置が進んだはずで 
あろ.

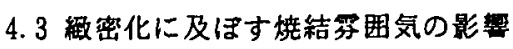

真空では，フラックス量2mass\%の1620K-60min焼 結で最高密度の94.5\%を得る。他方，アルコン罗团 気では，同し1620K-60min焼結でフラックス量1mass\% を越えると密度が大幅に減少し、実験した範囲で90\% を越えることがない：これは閉鎖気孔が消減するか 否かによる差と考えられる. Photo. 2は, 真空とア

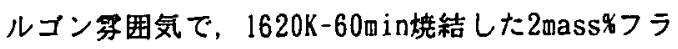
ックス試料の組織である。これによると，真空の焼 結体がスンレス鎆マトリックスとフラックスが贸 化したスラグから成って，気孔が殆ど残っていない のに対し，アルゴンで焼結す扎ば，マトリックス中 にスラグと気孔の両方が明らかに存在している．真 㞬の場合は，赎結の後期に生じる閉鎖気孔の消隇に 障害はないが，アルコン罗团気では，閉鎖気孔の中 にアルコンガスが残留して除去できないため，気孔 が残留してしまう”と考えられる。

フラックスの量の增大は，焼結を促進する一方で 閉鎖気孔の形成をも促進し、アルコン等囲気焼結で の密度上昇を妨害する，さらにフラックスは，焼結 後スラクに桨わって㙂結体中で体積を占めることに よっても，密度上昇を妨害する。このように、フラ ックス添加は密度上界に相反する撤きをするため， 添加量がある限度を越えると到遂密度が成少し，そ

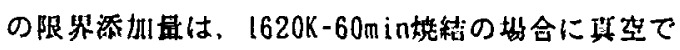
は2mass\%，アルコンガスではlmass\%である.

\section{5 結 蹁}

SUS316Lステンレス鋼粉にNa2 $\mathrm{B}_{4} \mathrm{O}$ 7をフラックスと して添加し，接結促進效果を䚴へて次の結果を得た。

1. ステンレス鋼粉柆子の間の $\mathrm{Na}_{2} \mathrm{~B}_{4} \mathrm{O}_{7}$ の存在は，閵 滑郩の役目をして粉末の压樎性を改善するか，低密 度のフラックスの添加は，他方で压㸮体の密度を減 少させる. 涯加量が多すきれれば，この二つの相反す ろ要因の中で後者の効果が大きくなり, 成形密度を 減少させる.

2. $\mathrm{Na}_{2} \mathrm{~B}_{4} \mathrm{O}_{7}$ の添加は，焼結密度を大幅に增加させ， 2mass\%添加の真空焼結では相対密度が94\%を越える。 この密度が100\%にならないのは，生したスラグが体
皘を占めるためである.

3. $\mathrm{Na}_{2} \mathrm{~B}_{4} \mathrm{O}$ ᄀ添加による栳結促進に最も大きく奇与 していろのは，多元系合金液相の発生に伴う一般的 な湤相焼結機櫣であろうと考えられる。

\section{文献}

1) D.P.Ferriss:The International Journal of Powder $\mathrm{Me}$ tallurgy and Powder Technology, 19(1983) 11.

2) I.Olefjord and L.Nyborg: Powder Metallurgy, 28(1985) 237.

3）森岡恭昭，渡辺侊尚，若林章治：㸮体および㸮 末治金，13(1966) 136.

4) R.M.Larsen and K.A.Thorsen: Powder Metallurgy, 37(1994) 61.

5）武田徽，田村皖司：体および物末治金，17 (1971) 220 .

6) R.L.Sands and J.F.Watkinson: Powder Metallurgy, 5(1960) 85 .

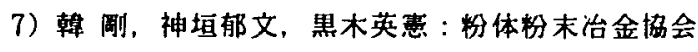
春季大会满演概要集，（1994）206.

8) A.Tiziani, A.Molinari, L.Fedrizzi, A.Tomasi and P.L. Bonora: Powder Metallurgy, 32(1989) 118.

9) W.F.Wang: Powder Metallurgy, 35(1992) 281.

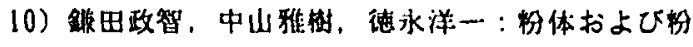
来治金. 38(1991) 529.

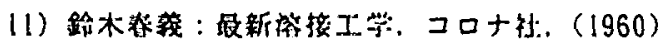
386.

12) Y.Tanaka and J.A.Lund: The Incernational Journal of Powder Metallurgy, 22(1986) 73.

13) J.A.Lund, Y.Tanaka and X.Qu: The International Journal of Powder Metallurgy, 24(1988) 301.

14）王虫文一只: 岩波理化学辞典第3 版。岩波费 店.（1978） 1260.

15) R.C.Weast and M.J.Astle: CRC Handbook of Chemistry and Physics, Edition 61st, CRC Press Inc., (1980-1981) B-146.

16) R.M.German:Powder Metallurgy Science, 2nd edition, Metal Powder Industries Federation, (1994) 274. 